\title{
MJN FACTORS RELATED TO DISASTER PREPAREDNESS AMONG NURSES: A SYTEMATIC REVIEW
}

\author{
Dewa Gede Sanjaya Putra*, Kuswantoro Rusca Putra, Noorhamdani AS \\ Faculty of Medicine, Universitas Brawijaya, Malang, Indonesia \\ *Corresponding Author's Email: sanjayaputradewagede@gmail.com
}

\begin{abstract}
Introduction: One-decade disasters that occur globally are the phenomena that will not stop but increase. This results in a high rate of injury, death, large numbers of infrastructure damages, and also enormous economic and personal loss to society. Nurses are in the frontline and have a very important role in all phases of disaster management. The purpose of writing this article is to review the factors of preparedness of nurses in disaster management. Methods: This is a literature review of scientific articles conducted from 2009 to 2019 on nurses' preparedness for disasters. The review was proceeded through several stages; making questions, identification, eligibility, article inclusion selection, screening, and appraisal. The selection process was listed in the review systematic framework and 8 article articles were obtained. The articles were then summarized and assessed by JBI in each article. Results: The review shows that nurse preparedness is related to several factors, namely; education level, years of work, previous disaster response experience, attendance in disaster simulation training, family preparedness, and self-regulation. Conclusion: Providing a sustainable education and training on disaster simulation that involves nurses in disaster mapping will increase nurses' confidence and preparedness in facing future disasters.
\end{abstract}

Keyword: Disaster, Preparedness, Nurses

\section{INTRODUCTION}

Disasters that occur globally are the phenomena that will not stop and increase, this will result in high rates of deaths and injuries, large numbers damages to infrastructure and enormous economic and personal losses for the community (Kayano et al., 2019). The number of deaths and injuries varies and depend on factors related to the nature of the disasters and the regional infrastructure where the disaster has occurred (Guha-Sapir et al., 2016).

Nurses are the largest sector of the workforce in health care and will be at the forefront. They are the first health professional to visit the victims for every disaster emergency response (Veenerma, 2015). Nurses have a very important role in disaster preparedness, especially nurses who work in emergency units or installations (Grochtdreis et al., 2016). Nurses have played an important part in disasters in all phases, including preparedness, mitigation, response and recovery/ rehabilitation (Miller \& Farra, 2012). Among those phases, disaster nursing requires a special attention on its planning and preparation (International Council of Nurse, 2009). The important role of nurses in disaster management must be considered to minimize the increasing global threats. In case of disas-ter it is very important for nurses to improve their competence in disaster preparedness (Achora \& Kamanyire, 2016).

Within the Sendai Framework it was found that there are four priorities in disaster risk manage-ment, namely 1). Understand disaster risk; 2). Strengthening disaster risk management to manage disaster risk; 3 ). Invest in disaster risk reduction for resilience and 4). Improve disaster prepared-ness for effective response and to rebuild better in terms of recovery, rehabilitation and reconstruc-tion (Surianto et al., 2019). A recent study found that nurses' preparedness in disaster management is still at the moderate to lower level (Labrague et al., 2018). Nurses also do not understand their exact role in disaster management (Duong, 2009). 


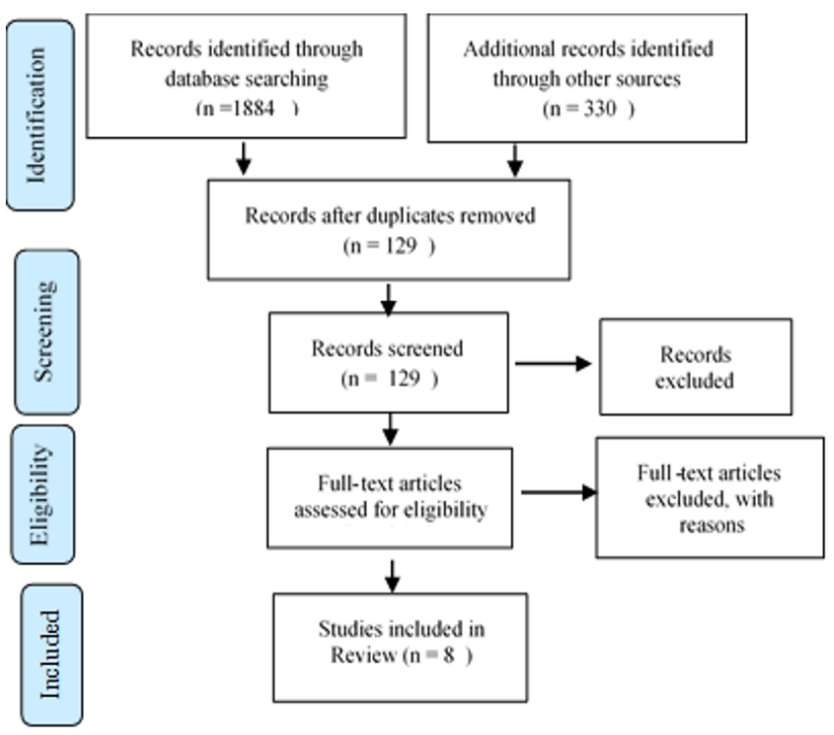

Figure 1: Flow chart of the selection process

\section{METHODOLOGY}

This study is a systematic review on factors that contribute to nurses' preparedness for disasters, through several electronic medical databases namely, ProQuest, Science Direct, and NCBI. The search keywords included: Nurses Role, Disaster Preparedness, and Disaster
Response. Those keywords are applied in a combination using conjunction "AND", i.e., 'Nurses Role and Disaster Preparedness and Disaster Response'. The author identifies the article by selecting settings on each database search page, namely: articles published between 20092019. Besides, the criteria for the articles included in this review are original research articles with a quantitative approach written in English. While theses, systematic reviews, qualitative studies, and articles that are not written in English are excluded.

The search was done by combining the three keywords with the combination "AND" resulted in 894 articles in Science Direct, 330 articles in NCBI and 990 articles in ProQuest. This number was reduced to 129 after the title and abstract review. It was found that 2085 articles are not relevant to the purpose of the review. The full text reading of the remaining articles produced 8 articles that were deemed suitable for review. The process followed to identify articles that are relevant for re-view is shown in the attached figure. After the authors determine the articles to be reviewed, all articles are summarized and assessed using the Joanna Briggs Institute check list (Joanna Briggs Institute, 2019). The summary of the results of each article is explained in the attached table below:

Table 1: Summary of Results of Each Article

\begin{tabular}{|c|c|c|c|c|c|c|c|}
\hline Author & Location & Sample & $\begin{array}{l}\text { Sampling } \\
\text { Method }\end{array}$ & $\begin{array}{l}\text { Study } \\
\text { Purposes }\end{array}$ & Study Design & Instrument & $\begin{array}{l}\text { Main } \\
\text { Findings }\end{array}$ \\
\hline $\begin{array}{l}\text { Ahayalimudin } \\
\text { \& Osman, } \\
\text { (2016) }\end{array}$ & Malaysia & $\begin{array}{l}196 \\
\text { (emergency } \\
\text { room nurses, } \\
\text { doctors and } \\
\text { medical } \\
\text { assistants) }\end{array}$ & $\begin{array}{l}\text { Simple } \\
\text { Random } \\
\text { Sampling }\end{array}$ & $\begin{array}{l}\text { This study } \\
\text { explores the } \\
\text { knowledge, } \\
\text { attitudes and } \\
\text { practices of } \\
\text { emergency } \\
\text { medical staff } \\
\text { towards } \\
\text { disaster } \\
\text { management. }\end{array}$ & cross-sectional & $\begin{array}{l}\text { The author makes } \\
\text { a questionnaire } \\
\text { through deepening } \\
\text { the literature } \\
\text { review. }\end{array}$ & $\begin{array}{l}\text { Sociodemograph } \\
\text { ic factors } \\
\text { studied, gender } \\
\text { and education } \\
\text { level were } \\
\text { significantly } \\
\text { associated with } \\
\text { improved } \\
\text { knowledge and } \\
\text { practice scores. } \\
\text { Work } \\
\text { experience, } \\
\text { involvement in } \\
\text { disaster response } \\
\text { and attending } \\
\text { disaster training } \\
\text { have a } \\
\text { significant } \\
\text { association with } \\
\text { higher practice } \\
\text { scores }\end{array}$ \\
\hline
\end{tabular}




\begin{tabular}{|c|c|c|c|c|c|c|c|}
\hline $\begin{array}{l}\text { Husna, } \\
\text { Hatthakit dan } \\
\text { Chaowalit, } \\
\text { (2011) }\end{array}$ & $\begin{array}{l}\text { Aceh, } \\
\text { Indonesia }\end{array}$ & 78 Nurses & $\begin{array}{l}\text { Purposive } \\
\text { Sampling }\end{array}$ & $\begin{array}{l}\text { Identifying the } \\
\text { level of } \\
\text { clinical skills } \\
\text { felt for } \\
\text { tsunami care } \\
\text { among nurses } \\
\text { in Banda } \\
\text { Aceh, } \\
\text { Indonesia, } \\
\text { To determine } \\
\text { the } \\
\text { relationship } \\
\text { between } \\
\text { clinical skills } \\
\text { perceived for } \\
\text { tsunami care } \\
\text { and } \\
\text { knowledge, } \\
\text { and clinical } \\
\text { experience } \\
\text { among nurses } \\
\text { in Banda } \\
\text { Aceh, } \\
\text { Indonesia }\end{array}$ & $\begin{array}{l}\text { Descriptive } \\
\text { correlational } \\
\text { study }\end{array}$ & $\begin{array}{l}\text { (Demographic } \\
\text { Data } \\
\text { Questionnaire } \\
\text { [DDQ], Nurses' } \\
\text { Clinical } \\
\text { Experience } \\
\text { Questionnaire } \\
\text { [NCEQ], Nurses' } \\
\text { Knowledge } \\
\text { Tsunami Care } \\
\text { Questionnaire } \\
\text { [NKTCQ], and } \\
\text { Tsunami Care } \\
\text { Questionnaire } \\
\text { [TCQ] }\end{array}$ & $\begin{array}{l}\text { Clinical } \\
\text { knowledge and } \\
\text { experience have } \\
\text { a significant low } \\
\text { positive } \\
\text { correlation with } \\
\text { nurses' clinical } \\
\text { skills perceptions } \\
\text { in caring for } \\
\text { post-tsunami } \\
\text { patients. }\end{array}$ \\
\hline $\begin{array}{l}\text { Jonson, } \\
\text { Pettersson, } \\
\text { Rybing, } \\
\text { Nilsson, \& } \\
\text { Prytz, (2017) }\end{array}$ & Swedia & $\begin{array}{l}13 \text { Chief of } \\
\text { Emergency } \\
\text { Care Nurse }\end{array}$ & $\begin{array}{l}\text { Total } \\
\text { Sampling }\end{array}$ & $\begin{array}{l}\text { Measuring } \\
\text { whether a } \\
\text { brief, small- } \\
\text { scale } \\
\text { computer- } \\
\text { based } \\
\text { simulation } \\
\text { exercise can } \\
\text { improve } \\
\text { general and } \\
\text { specific Self } \\
\text { Efficacy of } \\
\text { emergency } \\
\text { nurses and } \\
\text { disaster } \\
\text { management } \\
\text { skills }\end{array}$ & $\begin{array}{l}\text { Experimental } \\
\text { method with } \\
\text { pretest- } \\
\text { posttest design } \\
\text { in groups }\end{array}$ & $\begin{array}{l}\text { Self Efficacy } \\
\text { Disaster } \\
\text { Management } \\
\text { Questionnaire }\end{array}$ & $\begin{array}{l}\text { This study shows } \\
\text { that short } \\
\text { computer-based } \\
\text { simulation } \\
\text { exercises provide } \\
\text { opportunities for } \\
\text { head nurses to } \\
\text { improve } \\
\text { management } \\
\text { skills and } \\
\text { improve general } \\
\text { self-efficacy }\end{array}$ \\
\hline $\begin{array}{l}\text { Rizqillah \& } \\
\text { Suna, (2018) }\end{array}$ & $\begin{array}{l}\text { Central } \\
\text { Java, } \\
\text { Indonesia }\end{array}$ & 120 Nurses & $\begin{array}{l}\text { Convenience } \\
\text { Sample }\end{array}$ & $\begin{array}{l}\text { Explore the } \\
\text { disaster } \\
\text { preparedness } \\
\text { of Indonesian } \\
\text { nurses to } \\
\text { identify the } \\
\text { education and } \\
\text { training needs } \\
\text { of Indonesian } \\
\text { nurses }\end{array}$ & $\begin{array}{l}\text { Descriptive, } \\
\text { cross-sectional } \\
\text { Study }\end{array}$ & $\begin{array}{l}\text { Disaster } \\
\text { Preparedness } \\
\text { Evaluation Tool } \\
\text { ((Tichy et al., } \\
\text { 2009) }\end{array}$ & $\begin{array}{l}\text { Indonesian } \\
\text { emergency } \\
\text { nurses have a } \\
\text { moderate level of } \\
\text { disaster } \\
\text { preparedness. } \\
\text { Previous disaster } \\
\text { experience and } \\
\text { disaster training } \\
\text { or education are } \\
\text { positively related } \\
\text { to disaster } \\
\text { preparedness }\end{array}$ \\
\hline
\end{tabular}




\begin{tabular}{|c|c|c|c|c|c|c|c|}
\hline $\begin{array}{l}\text { Park \& Kim, } \\
\text { (2017) }\end{array}$ & $\begin{array}{l}\text { South } \\
\text { Korea }\end{array}$ & $\begin{array}{l}231 \\
\text { Emergency } \\
\text { Care Nurses }\end{array}$ & $\begin{array}{l}\text { Convenience } \\
\text { Sampling }\end{array}$ & $\begin{array}{l}\text { To identify } \\
\text { factors } \\
\text { affect the core } \\
\text { competencies } \\
\text { of emergency } \\
\text { nurse disaster }\end{array}$ & $\begin{array}{l}\text { Descriptive, } \\
\text { cross-sectional }\end{array}$ & $\begin{array}{l}\text { Nurses' } \\
\text { Experiences of } \\
\text { Disaster scale, } \\
\text { Attitudes toward } \\
\text { Disaster Manage- } \\
\text { ment scale, } \\
\text { Nurses' } \\
\text { Knowledge about } \\
\text { Disaster scale, } \\
\text { Disaster Nursing } \\
\text { Core } \\
\text { Competencies } \\
\text { scale }\end{array}$ & $\begin{array}{l}\text { These findings } \\
\text { indicate that the } \\
\text { main } \\
\text { competencies of } \\
\text { nurses in } \\
\text { emergency } \\
\text { nurses can be } \\
\text { improved } \\
\text { through } \\
\text { education and } \\
\text { training } \\
\text { programs that } \\
\text { increase their } \\
\text { disaster } \\
\text { preparedness. }\end{array}$ \\
\hline $\begin{array}{l}\text { Nofal, } \\
\text { Alfayyad, } \\
\text { Khan, Al Aseri, } \\
\text { \& Abu- } \\
\text { Shaheen, (2018) }\end{array}$ & $\begin{array}{l}\text { Mecca, } \\
\text { Saudi } \\
\text { Arabia }\end{array}$ & $\begin{array}{l}189 \text { doctors } \\
\text { and } \\
\text { emergency } \\
\text { room nurses }\end{array}$ & $\begin{array}{l}\text { Convenience } \\
\text { Sampling }\end{array}$ & $\begin{array}{l}\text { To assess } \\
\text { knowledge, } \\
\text { practices, and } \\
\text { attitudes about } \\
\text { disasters and } \\
\text { emergency } \\
\text { preparedness } \\
\text { among } \\
\text { Emergency } \\
\text { Department } \\
\text { (ED) staff. } \\
\text {. }\end{array}$ & $\begin{array}{l}\text { Cross- } \\
\text { sectional } \\
\text { Survey }\end{array}$ & $\begin{array}{l}\text { Emergency } \\
\text { Preparedness } \\
\text { Information } \\
\text { Questionnaire } \\
\text { (EPIQ) }\end{array}$ & $\begin{array}{l}\text { Participants with } \\
\text { more than } 5 \\
\text { years experience } \\
\text { had statistically } \\
\text { significant } \\
\text { knowledge scale } \\
\text { scores (p = } \\
0.009 \text { ) for } \\
\text { disaster and } \\
\text { emergency } \\
\text { preparedness. } \\
\text { Overall, } 186 \\
\text { (98.4\%) } \\
\text { respondents } \\
\text { believed that } \\
\text { training was } \\
\text { needed for all } \\
\text { health workers. }\end{array}$ \\
\hline $\begin{array}{l}\text { Lim, Lim, \& } \\
\text { Vasu, (2013) }\end{array}$ & Singapore & $\begin{array}{l}1534 \\
\text { Health } \\
\text { workers } \\
\text { (doctors, } \\
\text { nurses and } \\
\text { other } \\
\text { officers) }\end{array}$ & $\begin{array}{l}\text { Convenience } \\
\text { Sampling }\end{array}$ & $\begin{array}{l}\text { To know } \\
\text { perception } \\
\text { Health } \\
\text { workers to } \\
\text { their } \\
\text { individual and } \\
\text { institutional } \\
\text { readiness } \\
\text { for disaster }\end{array}$ & $\begin{array}{l}\text { cross-sectional } \\
\text { survey }\end{array}$ & $\begin{array}{l}\text { The author makes } \\
\text { a questionnaire } \\
\text { through deepening } \\
\text { the literature } \\
\text { review }\end{array}$ & $\begin{array}{l}\text { Experience in } \\
\text { previous disaster } \\
\text { response, } \\
\text { attendance at } \\
\text { disaster training, } \\
\text { the support of } \\
\text { family and peers } \\
\text { are factors in } \\
\text { individual } \\
\text { preparedness in } \\
\text { facing disasters. }\end{array}$ \\
\hline $\begin{array}{l}\text { Baack S \& } \\
\text { Alfred D }\end{array}$ & Texas & $\begin{array}{l}620 \\
\text { Nurses }\end{array}$ & $\begin{array}{l}\text { Purposive } \\
\text { Sampling }\end{array}$ & $\begin{array}{l}\text { This research } \\
\text { study was } \\
\text { conducted to } \\
\text { illustrate } \\
\text { the current } \\
\text { status of } \\
\text { nurses' } \\
\text { preparedness } \\
\text { to deal with } \\
\text { illnesses to } \\
\text { help } \\
\text { communities } \\
\text { and the health } \\
\text { care system } \\
\text { strengthen } \\
\text { their } \\
\text { emergency } \\
\text { response } \\
\text { programs. } \\
\text { their } \\
\text { preparedness } \\
\text { in facing } \\
\text { disaster } \\
\text { and how } \\
\text { nurses get this } \\
\text { perception. }\end{array}$ & $\begin{array}{l}\text { Descriptive } \\
\text { and } \\
\text { correlational } \\
\text { design }\end{array}$ & $\begin{array}{l}\text { Emergency } \\
\text { Preparedness } \\
\text { Information } \\
\text { Questionnaire } \\
\text { (EPIQ), Self- } \\
\text { Regulation Scale, } \\
\text { Angket Kepuasan } \\
\text { Kerja } \\
\text { (Wieck et al., } \\
2009 \text { ) }\end{array}$ & $\begin{array}{l}\text { A confident } \\
\text { nurse is more } \\
\text { likely to have } \\
\text { previous } \\
\text { experience in a } \\
\text { disaster. Self- } \\
\text { regulation } \\
\text { behavior } \\
\text { (motivation) is a } \\
\text { significant } \\
\text { predictor of } \\
\text { nurses' } \\
\text { competency } \\
\text { perceptions for } \\
\text { managing } \\
\text { disasters. Work } \\
\text { environment (job } \\
\text { satisfaction) is } \\
\text { not a determinant } \\
\text { of disaster } \\
\text { preparedness. }\end{array}$ \\
\hline
\end{tabular}




\section{RESULTS}

From the results of the review conducted by the author it can be concluded that there are six factors that contribute to the preparedness of nurses in disaster management.

\section{Level of Education}

Nurses who have a degree of undergraduate education have a positive correlation with the high level of nurses' knowledge and skills in disaster management (Ahayalimudin \& Osman, 2016).

\section{Year of Work}

Length of work shows a significant and positive correlation on increasing nurse prepared-ness in management and responding to disasters (Ahayalimudin \& Osman, 2016). In other studies it was also found that nurses who worked more than 5 years in health institutions will have more knowledge and skills in disaster management (Nofal et al., 2018). The work period is also stated to have a strong and positive relationship to the perception of emer-gency nurse preparedness in Indonesia in preparing themselves for future disasters (Rizqillah \& Suna, 2018). The clinical experience (years of work) of nurses was also conveyed to be an important factor that had a positive correlation in increasing knowledge and skills in providing nurse care to patients in Post-Tsunami Aceh (Husna, Hatthakit \& Chaowalit, 2011).

\section{Experience in Previous Disaster Response}

The selected articles in this review also expose the relationship between nurses' experience in disaster response and their preparedness. Nurses involved in responding to disasters have a positive and significant correlation with the improvement of their knowledge and skills in future disaster management (Ahayalimudin \& Osman, 2016), while those who have never been exposed to disasters in their area have less knowledge about the dangers of other dis-asters (Rizqillah \& Suna, 2018). Besides, nurses' experience in responding to major disas-ters give a positive impact on the perception of competency they have (Baack \&Alfred, 2013). Other study also found that previous disaster-related experiences were important findings and had the strongest influence on the main competencies of emergency room nurses in South Korea in terms of future disaster management (Park \& Kim, 2017).
Conclu-sively, previously reported studies found that disaster experiences will be able to positively enhance nurses' knowledge and competency in disaster preparedness.

\section{Disaster Simulation Training}

A study revealed that nurses who attended previous disaster simulation training had a positive correlation with their knowledge and skills in caring for patients after the Aceh Tsunami. The findings of this study could serve as evidence for stakeholders in the hospital to prepare nursing staff for nurses' knowledge and skills for tsunami care by providing regular disaster and emergency training to respond to future disasters (Husna, Hatthakit \& Chaowalit, 2011). It was also found in another study that nurses who worked in emergency departments, and those who previously attended disaster management training had high self-confidence when facing an impending disaster (Rizqillah \& Suna, 2018). The provision of disaster simulations and ongoing training by hospitals provides a positive contribution to improving the main competencies of emergency room nurses in responding when a disasters occur (Park \& Kim, 2017). Giving a short simulation through computer media also has a positive correlation to the increase the confidence of the head nurse in responding to disaster occurances (Jonson et al., 2017). The presence of officers in every training and disaster simulation is very important in improving their knowledge and skills in dealing with future disasters (Lim, Lim \& Vasu, 2013).

\section{Family Readiness and Support}

Nurses whose families that have adequate readiness and could plan for disaster, are given a support to be able to give a good response when a disaster occurs. Sharing information about the scope of work of health workers with their family members will be beneficial. This will enable family members to understand and support their work, especially in the event of a disaster (Lim, Lim \& Vasu, 2013).

\section{Self-Regulation}

Self-regulation in this case is an effort made by nurses to regulate themselves. So that, they are able to survive and can provide the best response when a disaster occurs. Self-Regulation, which relates to motivation, has a positive and strong correlation to the increase in nurse preparedness for disaster management (Baack \& Alfred, 2013). 


\section{DISCUSSION}

From the articles reviewed, it was found that there are six predominant factors that con-tribute to the nurses' preparedness in disaster management, namely; the level of education, years of work, experience in previous disaster response, disaster simulation training, family readiness and support, Self-Regulation. In terms of nurses level of education, effective disaster response is influ-enced by a high level of education, a long duration of education, good learning, and an abundance of disaster knowledge and skills from nurses $(\mathrm{Xu} \&$ Zeng, 2016). As the frontline of health ser-vices during disasters, nurses must be equipped with knowledge and readiness in responding to disasters in all phases (Hutton, Veenema \& Gebbie, 2016).

The availability of knowledge resources in the form of difficult to find appropriate libraries and internet networks were also obstacle for nurses to increase their capacity to obtain the latest knowledge in disaster preparedness (Sangkala \& Gerdtz, 2018). The availability of information and literature is a key factor in supporting clinical staff to keep their knowledge updated and follow current practices. Limited access to published literature will reduce nurses' abilities in clinical prac-tice (Melnyk \& Ellen, 2014). As a result, nurses who lack knowledge and readiness will have diffi-culty in providing adequate care and support for disaster victims and their families (Arbon etal., 2013).

Nurses' knowledge and skills in nurse preparedness are reported to have a significant rela-tionship with experience of dealing with previous disasters and the frequency of their attendance in disaster simulation training (Labrague et al., 2018). The involvement of nurses in mapping poten-tial disasters that will occur, providing education through disaster simulations to nurses will be able to increase their confidence in dealing with future disasters (Al Khalailah, Bond \& Alasad, 2012). Another study reported a significant and positive correlation between the frequency of training for nurses and their confidence (Duong, 2009). In other words, with more training on disaster man-agement they have higher confidence in their abilities with disaster management (Naser \& Saleem, 2018).

Disaster management training must be provided for all nurses, especially those who work in nongovernment hospitals, who have not received training on disaster management, to increase their knowledge in responding to any possible disasters. The more nurses attending disaster simulation exercises will increase nurses' confidence in dealing with actual disasters in the future (Vincent, Berg \& Ikegami, 2009; Morrison \& Catanzaro, 2010; Alim, Kawabata \& Nakazawa, 2015; Jonson et al., 2017). However, it is still found in some countries a lack of nurse awareness and awareness to attend training related to increasing the capacity of nurses in disaster preparedness (Usher et al., 2015). Disaster-related training must be included in nursing education programs and continuing education courses to help hospital nurses recognize and improve their own preparedness for disas-ter response (Tzeng et al., 2016).

The preparedness of health workers, especially nurses, is not only related to how they re-ceive training and continue education, but family support in the form of family preparedness also has an important role for nurses to be able to provide their best response in disaster management (Lim, Lim \& Vasu, 2013). Nurses' who are involved in family planning and preparedness in facing disasters are eight times more willing to attend their workplaces in disasters (Arbon et al., 2013). Other research also shows nurses who have higher personal preparedness, such as disaster plans at their homes, have a higher level of willingness to attend their workplaces in disasters (Goodhue et al., 2012).

Besides that nurses in responding to disasters require motivation and strength to organize them-selves so that they are truly prepared to face the conditions they experience (Baack \& Alfred, 2013). The first phase when they are confronted with an actual disaster is a feeling of being unpre-pared because they are taken aback by seeing the catastrophic disaster and the impact of the dam-age resulting from the disaster that occurred (Li. et al., 2017). After being hit by reality, the process of adapting to these circumstances requires extensive professional experience (Li et al., 2015).

\section{CONCLUSION}

This literature review aims to identify the factors that contribute to the nurses' preparedness in disaster management. The studies reviewed has elucidated that there are six main factors which are proven to promote nurses' preparedness, namely; the level of education, year of work, experi-ence in previous disaster response, disaster simulation training, family readiness and support, Self-Regulation. Those six factors are concluded to be beneficial for the nurses' competency both in the aspects of knowledge and skill. Therefore, this article would suggest the importance of continuous 
professional development for nurses, especially in disaster management. Thus, providing training and education may not only be about knowledge that increases their skills in helping victims but must also include how they should be encouraged to have a strong self-regulation of a risk-filled challenge that would enforce their readiness when an actual disaster occurs.

\section{Conflict of Interests}

The authors declare that they have no conflict of interest.

\section{ACKNOWLEDGEMENT}

The authors are thankful to the institutional authority for completion of the work.

\section{REFERENCES}

Achora, S. \& Kamanyire, J.K. (2016). Disaster preparedness: Need for inclusion in undergraduate nursing education. Sultan Qaboos University Medical Journal, 16(1), pp e15-e19.

Ahayalimudin, N.A. \& Osman, N.N.S. (2016). Disaster management: Emergency nursing and medical personnel's knowledge, attitude and practices of the East Coast region hospitals of Malaysia', Australasian Emergency Nursing Journal. College of Emergency Nursing Australasia, 19(4), pp 203-209.

Al Khalailah, M.A., Bond, E. \& Alasad, J.A. (2012). Jordanian nurses' perceptions of their preparedness for disaster management. International Emergency Nursing, 20(1), pp 14-23.

Alim, S., Kawabata, M. \& Nakazawa, M. (2015). Evaluation of disaster preparedness training and disaster drill for nursing students'. Nurse Education Today, 35(1), pp 25-31.

Arbon, P., Ranse, J., Cusack, L., Considine, J., Shaban, R.Z., Woodman, R.J., Bahnisch, L., Kako, M., Hammad, K. \& Mitchell, B., (2013). Australasian emergency nurses' willingness to attend work in a disaster: A survey. Australasian Emergency Nursing Journal, 16(2), pp 52-57.

Baack, S. \& Alfred, D. (2013). Nurses' preparedness and perceived competence in managing disasters. Journal of Nursing Scholarship, 45(3), pp 281-287.

Duong, K. (2009). Disaster education and training of emergency nurses in South Australia. Australasian Emergency Nursing Journal, 12(3), pp 86-92.

Goodhue, C.J., Burke, R.V., Ferrer, R.R., Chokshi, N.K., Dorey, F. \& Upperman, J.S. (2012). Willingness to Respond in a Disaster : A Pediatric Nurse Practitioner National Survey. Journal of Pediatric Health Care, 26(4), pp e7-e20.

Grochtdreis, T., de Jong, N., Harenberg, N., Görres, S. \& Schröder-Bäck, P. (2016). Nurses’ roles, knowledge and experience in national disaster pre-paredness and emergency response: A literature review. South Eastern European Journal of Public Health, 7(1), pp 1-19.

Guha-Sapir, D., Vos, F., Below, R. \& Ponserre, S. (2016). Annual Disaster Statistical Review 2016: The numbers and trends. Brussels: The Centre for Research on the Epidemiology of Disasters (CRED).

Husna, C., Hatthakit, U. \& Chaowalit, A. (2011). Do knowledge and clinical experience have specific roles in perceived clinical skills for tsunami care among nurses in Banda Aceh, Indonesia? Australasian Emergency Nursing Journal, 14(2), pp 95-102.

Hutton, A., Veenema, T.G. \& Gebbie, K. (2016). Review of the International Council of Nurses (ICN) Framework of Disaster Nursing Competencies. Prehospital and Disaster Medicine, 31(6), pp 680-683.

International Council of Nurse (2009). ICN Framework of Disaster Nursing Competencies, WHO and ICN. Geneva, Switzerland: International Council of Nurses.

Joanna Briggs Institute (2019). CRITICAL APPRAISAL TOOLS. Retrieved from: https://joannabriggs.org/research/ critical-appraisal-tools.html. 
Jonson, C.O., Pettersson, J., Rybing, J., Nilsson, H. \& Prytz, E. (2017). Short simulation exercises to im-prove emergency department nurses' self-efficacy for initial disaster management: Controlled before and after study. Nurse education today, 55, pp 20-25.

Kayano, R., Chan, E.Y., Murray, V., Abrahams, J. \& Barber, S.L. (2019). WHO thematic platform for health emergency and disaster risk management research network (TPRN): Report of the kobe expert meeting. International Journal of Environmental Research and Public Health, 16(7), pp 1-6.

Labrague, L.J., Hammad, K., Gloe, D.S., McEnroe-Petitte, D.M., Fronda, D.C., Obeidat, A.A., Leocadio, M.C., Cayaban, A.R. \& Mirafuentes, E.C. (2018). Disaster Preparedness Among Nurses: A Systematic Review of Literature. International Nursing Review, 65(1), pp 41-53.

Li, Y.H., Li, S.J., Chen, S.H., Xie, X.P., Song, Y.Q., Jin, Z.H. \& Zheng, X.Y. (2017). Disaster nursing experiences of Chinese nurses responding to the Sichuan Ya' an earthquake. International nursing review, 64(2), pp 309-317.

Li, Y., Turale, S., Stone, T.E. \& Petrini, M. (2015). A grounded theory study of “turning into a strong nurse": Earthquake experiences and perspectives on disaster nursing education. Nurse Education Today, 35(9), pp e43-e49.

Lim, G.H., Lim, B. L. \& Vasu, A. (2013). Survey of Factors Affecting Health Care Workers' Perception Towards Institutional and Individual Disaster Preparedness. Prehospital and Disaster Medicine, 28(4), pp 353-358.

Melnyk, B.M. \& Ellen, F.-O. (2014). Evidence-based Practice in Nursing \& Healthcare: A Guide to Best Practice. $3^{\text {rd }}$ edition. Philadelphia: Wolters Kluwer Health.

Miller, E.T. \& Farra, S. (2012). Disaster preparedness, a rehabilitation nursing priority. Rehabilitation Nursing, 37(3), pp 95-96.

Morrison, A.M. \& Catanzaro, A.M. (2010). High-fidelity simulation and emergency preparedness. Public Health Nursing, 27(2), pp 164-173.

Naser, W.N. \& Saleem, H.B. (2018). Emergency and Disaster Management Training; Knowledge and Attitude of Yemeni Health Professionals- a Cross-sectional Study. BMC Emergency Medicine, 18(1).

Nofal, A., Alfayyad, I., Khan, A., Al Aseri, Z. \& Abu-Shaheen, A. (2018). Knowledge, attitudes, andpractices of emergencydepartment staff towards disaster and emergency preparedness at tertiary health care hospital in central Saudi Arabia. Saudi Medical Journal, 39(11).

Park, H.Y. \& Kim, J.S. (2017). Factors influencing disaster nursing core competencies of emergency nurses. Applied Nursing Research. Elsevier Inc., 37, pp 1-5.

Rizqillah, A.F. \& Suna, J. (2018). Indonesian emergency nurses' preparedness to respond to disaster: A descriptive survey. Australasian Emergency Care, 21(2), pp 64-68.

Sangkala, M.S. \& Gerdtz, M.F. (2018). Disaster preparedness and learning needs among community health nurse coordinators in South Sulawesi Indonesia. Australasian Emergency Care, 21(1), pp 23-30.

Surianto, S., Alim, S., Nindrea, R.D. \& Trisnantoro, L. (2019). Regional policy for disaster risk management in developing countries within the Sendai Framework: a systematic review. Open access Macedonian Journal of Medical Sciences, 7(13), p 2213.

Tichy, M., Bond, A.E., Beckstrand, R.L. \& Heise, B. (2009). Nurse Practitioners' perception of disaster pre-paredness education. American Journal of Nurse Practitioners, 13(1), pp 10-22.

Tzeng, W.C., Feng, H.P., Cheng, W.T., Lin, C.H., Chiang, L.C., Pai, L. \& Lee, C.L. (2016). Readiness of hospital nurses for disaster responses in Taiwan: A cross-sectional study. Nurse Education Today, 47, pp 37-42.

Usher, K., Mills, J., West, C., Casella, E., Dorji, P., Guo, A., Koy, V., Pego, G., Phanpaseuth, S., Phouthavong, O. \& 
Sayami, J. (2015). Cross-sectional survey of the disaster preparedness of nurses across the Asia-Pacific region. Nursing and Health Sciences, 17(4), pp 434-443.

Veenerma, T. G. (2015). Disaster Nursing and Emergency Preparedness for Chemical, Biological, and Radiological Terrorism and other Hazards. $3^{\text {rd }}$ edition. New York: Springer Publishing Company, LLC.

Vincent, D. S., Berg, B. W. \& Ikegami, K. (2009). Mass-casualty triage training for international healthcare workers in the Asia-Pacific region using manikin-based simulations. Prehospital and Disaster Medicine, 24(3), pp 206-213.

Xu, Y. \& Zeng, X. (2016). Necessity for disaster-related nursing competency training of emergency nurses in China. International Journal of Nursing Sciences, 3(2), pp 198-201. 